\title{
PENGARUH TANAH BEKAS MACAM-MACAM BIOAKTIVATOR DAN MIKORIZA SERTA KOMBINASI PUPUK ANORGANIK TERHADAP PERTUMBUHAN DAN HASIL TANAMAN KEDELAI (Glycine max L. Merril)
}

\author{
Oleh*Zulfanur Trirahmah**Ir. Hj. Fiana Podesta, MP. dan **Ir. H. Usman Yasin, M.Si. \\ (*Alumni FP UMB dan **Dosen FP UMB)
}

\begin{abstract}
ABSTRAK
Penelitian ini bertujuan untuk mengatahui pengaruh penggunaan tanah bekas macam-macam bioaktivator Mikoriza dengan kombinasi pupuk anorganik terhadap pertumbuhan dan hasil tanaman kedelai (Glycine max L. Merril). Penelitian ini dilaksanakan di Jl. Danau Raya No. 59, Panorama, Singaran Pati, Kota Bengkulu menggunakan Rancangan Acak Lengkap (RAL) faktorial dengan 2 faktor yaitu faktor pertama bioaktivator mikoriza (M): M1 (Bioaktivator Mikoriza Ragi), M2 : (Bioaktivator Mikoriza Nasi Basi), M3 (Bioaktivator Mikoriza Rumen Sapi), sedangkan faktor kedua kombinasi pupuk anorganik (P); P1 (12,5 kg Urea/ha + $100 \mathrm{~kg} \mathrm{SP36/ha}+50 \mathrm{~kg} \mathrm{KCL} / \mathrm{ha}), \mathrm{P} 2$ (25 kg Urea/ha + $50 \mathrm{~kg} \mathrm{SP36/ha}+50 \mathrm{~kg} \mathrm{KCL} / \mathrm{ha})$, P3 $(25 \mathrm{~kg}$ Urea/ha $+100 \mathrm{~kg} \mathrm{SP36/ha}+25 \mathrm{~kg}$ $\mathrm{KCL} / \mathrm{ha}$ ), masing-masing perlakuan diulang sebanyak $3 \mathrm{kali}$. Hasil data dianalisis menggunakan Analisis Sidik Ragam (ANOVA) dan apabila berbeda nyata dilakukan uji lanjut Duncan's Multiple Range (DMRT) taraf 0,5\%. Hasil penggunaan tanah bekas dengan macam bioaktivator mikoriza (rumen sapi) menunjukkan pengaruh yang nyata terhadap berat polong kering tanaman kedelai (Glycine $\max$ L. Merril), Sedangkan pemberian kombinasi pupuk anorganik berpengaruh nyata terhadap tinggi tanaman pada umur 28 HST. Penggunaan tanah bekas macam bioaktivator mikoriza dengan kombinasi pupuk anorganik tidak berpengaruh nyata terhadap tinggi tanaman, jumlah daun, jumlah daun, panjang akar, berat basah tanaman, berat kering tanaman, berat polong basah, berat polong kering, jumlah polong isi pertanaman, jumlah polong hampa (cipo), jumlah biji pertanaman, berat biji pertanaman, berat 100 biji.
\end{abstract}

Kata kunci : kedelai, tanah bekas bioaktivator dan mikoriza, kombinasi pupuk anorganik.

\begin{abstract}
ZULFANUR TRIRAHMAH. Effect of Past Varied Bioactivators and Mycorrhiza application Soil and Combination of Inorganic Fertilizers on Growth and Yields of Soybean (Glycine max L. Merril) Agrotechnology Students, Faculty of Agriculture and Animal Husbandry, Muhammadiyah University of Bengkulu. Under the Advisory of Ir. Hj. Fiana Podesta, MP. As the Advisor and Ir. H. Usman Yasin, M. Si. As the Co-Advisor.

This study aims to determine the effect of the used soil of bioactivators and mycorrhizae application with a combination of inorganic fertilizers on the growth and yield of soybean plants (Glycine max L. Merril). This research was conducted at Jl. Danau Raya No. 59, Panorama, Singaran Pati, Bengkulu City using a factorial Complete Randomized Design (CRD) with 2 factors: the first factor was bioactivator and mycorrhiza (M): M1 (Bioactivator and Mycorrhizal Yeast), M2: (Bioactivator and spoiled Rice Mycorrhiza), M3(Bioactivator and Cow Rumen Mycorrhiza), while the second factor was combination of inorganic fertilizer (P); P1 (12.5 kg Urea / ha $+100 \mathrm{~kg} \mathrm{SP} 36 / \mathrm{ha}+50 \mathrm{~kg}$ $\mathrm{KCL} / \mathrm{ha}), \mathrm{P} 2$ (25 kg Urea / ha + $50 \mathrm{~kg} \mathrm{SP} 36 / \mathrm{ha}+50 \mathrm{~kg} \mathrm{KCL} / \mathrm{ha}), \mathrm{P} 3$ (25 kg Urea / ha + $100 \mathrm{~kg}$ $\mathrm{SP} 36 / \mathrm{ha}+25 \mathrm{~kg} \mathrm{KCL} / \mathrm{ha})$, each treatment was repeated 3 times. The results of the data were analyzed using Analysis of Variance (ANOVA) and if it is significantly different, further testing of $0.5 \%$ Duncan's Multiple Range (DMRT) was $0.5 \%$ will be applied. The results of varied used soil
\end{abstract}


with bioactivator and mycorrhizal (cattle rumen) showed a significant effect on the dry weight of soybean pods (Glycine max L. Merril), while the application of inorganic fertilizers significantly affected the plant height at 28 DAP. The use of used soils such as bioactivators and mycorrhizae in combination with inorganic fertilizers did not significantly affect plant height, number of leaves, root length, plant wet weight, plant dry weight, wet pod weight, dry pod weight, number of plant filled pods, number of flat pods, number of seeds per plant, plant seeds weight, weight on 100 seeds.

Keywords: soybean, bioactivator and mycorrhizal soil, combination of inorganic fertilizer. 


\section{BAB I}

\section{PENDAHULUAN}

\subsection{Latar Belakang}

Kacang kedelai (Glycine max L.Merril) merupakan salah satu tanaman polong-polongan yangkandungan proteinnya tinggi, dapat menggantikan protein dari hewani, banyak mengandung karbohidrat dan minyak nabati. Dibandingkan dengan protein hewani, protein yang berasal dari kacang kedelai lebih murah sehingga lebih terjangkau oleh masyarakat. Setiap 100 gr kedelai mengandung $18 \%$ lemak, $35 \%$ karbohidrat, $8 \%$ air, 330 kalori, $35 \%$ protein dan $5,25 \%$ mineral. Kedelai merupakan bahan yang digunakan sebagai dasar pembuatan tempe, tahu, tauco, kecap, tauge dan sebagai bahan campuran makanan ternak. Banyak masyarakat yang sadar akan pentingnya untuk mengkonsumsi makanan yang sehat pengganti protein hewani maka kebutuhan akan kedelai terus meningkat seperti tepung kedelai yang merupakan bahan baku untuk membuat susu, keju, roti, kue dan lain-lain. Pada industri yang berbahan dasar kedelai bisa dihasilkan produk-produk non makanan, seperti kertas, cat cair, tinta cetak, tekstil dan mikrobiologi (Suhaeni, 2007).

Menurut BPS (2016), produksi kedelai di Provinsi Bengkulu mengalami penurunan produksi yang hanya mencapai 4.666 ton dibandingkan tahun 2015 yang mampu memperoleh sebanyak 5.388 ton kedelai biji kering. Sedangkan kebutuhan akan kacang kedelai untuk kebutuhan di Provinsi Bengkulu masih didatangkan dari daerah lain seperti dari Provinsi Lampung dan Provinsi Jawa. Penurunan produksi kedelai ini disebabkan oleh berkurang luas lahan panen.

Di Indonesia kedelai dapat tumbuh dan berproduksi dengan baik di dataran rendah sampai ketinggian 900 meter di atas permukaan laut (mdpl). Tanaman kedelai mempunyai daya adaptasi terhadap berbagai jenis tanah. Pada lahan yang baru pertama kali ditanami kedelai, benih perlu dicampur oleh Rhizobium, apabila tidak tersedia dapat digunakan tanah bekas pertanaman kedelai (Atman, 2014). Salah satu upaya yang dilakukan untuk meningkatkan produksi kedelai, dengan pemberian pupuk untuk mencukupi unsur hara tanaman. Jenis pupuk yang potensial digunakan adalah pupuk organik yang berasal dari darah sapi. Pupuk organik tepung darah sapi dapat digunakan apabila sudah difermentasi dengan cara menggunakan bioaktivator yaitu dengan menggunakan nasi basi, ragi, dan rumen sapi, menurut penelitian (Nopriansyah, Fiana, Suryadi, 2017). Bioaktivator bukan lah pupuk, melainkan bahan yang mengandung mikroorganisme efektif yang dapat membantu meningkatkan kapasitas fotosintesis pada tanaman, meningkatkan kwalitas bahan organik sebagai pupuk (Wahyono, 2010).

Menurut dari penelitian (Angga, Podesta, Fitriani, 2017) Pemberian Bioaktivator darah sapi $30 \%$ dan jenis varietas kedelai, Bioaktivator yang digunakan yaitu E4 $200 \mathrm{cc}$, M-bio $200 \mathrm{cc}$, nasi basi 1kg, ragi 90 gr, dan MOL $1 \mathrm{~kg}$. Tepung darah merupakan hasil ikutan ternak yang dapat dimanfaatkan sebagai sumber protein. Menurut Nuranto (2008) tepung yang diolah dari darah sapi memiliki kandungan protein, nitrogen alami $(\mathrm{N})$ asam amino yang tinggi serta sedikit fosfor(P). Menurut (Fitri, Dery, Sylvi dan Vivi Yarni, 2012), kandungan yang terdapat pada darah sapi ini mengandung Corganik sebesar $0,2 \%$, Nitrogen $5,5 \%$, Phospor 37,70 \% dan kalium sebesar 0,12\%. Menggunakan pupuk organik seperti tepung darah sapi dapat diaplikasikan dengan pupuk hayati Mikoriza. Penambahan Mikoriza pada budidaya tanaman dapat memberikan manfaat yang tinggi yaitu mampu meningkatkan produksi pada tanaman (Purnomo, 2008). Cendawan Mikoriza memiliki manfaat di dunia pertanian, diantaranya yakni membantu meningkatkan penyerapan hara tanaman terutama unsur $\mathrm{P}$, mampu meningkatkan ketahanan terhadap kondisi kekeringan, penyakit maupun kondisi tidak menguntungkan lainnya. Cendawan Mikoriza ini dapat dijadikan salah satu teknologi dalam membantu terhadap proses efisiensi pemupukan hara tanaman (Wicaksono, Rahayu, Samanhudi, 2014).

Untuk meningkatkan pertumbuhan dan hasil kedelai dapat dilakukan dengan 
penggunaan pupuk anorganik yaitu Urea sebanyak $25 \mathrm{~kg} / \mathrm{ha}$, pupuk SP36 sebanyak 100 $\mathrm{kg} / \mathrm{ha}$, pupuk KCl) $50 \mathrm{~kg} / \mathrm{ha}$ (Atman, 2014). Tanaman kedelai hanya membutuhkan Urea dalam jumlah kecil, sedangkan kebutuhan SP36 dan $\mathrm{KCl}$ yang cukup tinggi. Pupuk ini merupakan pupuk tunggal yang sangat berguna untuk pertumbuhan dan produksi tanaman.

Hasil analisis yang dilakukan di Laboratorium tanah Balai Penelitian Tanaman Pangan (BPTP) Bengkulu tahun 2019 menunjukkan bahwa tanah yang akan digunakan dari penelitian Saputri, Milyati (2018) yang menggunakan pupuk tepung darah sapi dengan macam bioaktivator dan Mikoriza memiliki kandungan N 0,18 \%, $\mathrm{P}$ 44,13 ppm, K 0,63 cmol(+)/kg, dan $\mathrm{Ph} \mathrm{4,87}$ (Bioaktivator Mikoriza + Nasi Basi), N 0,20 \%, P 32,93 ppm, K 0,56 cmol(+)/kg, dan $\mathrm{Ph}$ 4,76 (Bioaktivator Mikoriza + Rumen), $\mathrm{N}$ 0,30 \%, P 24,47 ppm, K 0,12 cmol(+)/kg dan $\mathrm{Ph}$ 4,86 (Bioaktivator Mikoriza + Ragi). Jika dibandingkan dengan standar kandungan hara tanah $\mathrm{N} \mathrm{0,4 \% ,} \mathrm{P} \mathrm{0,1} \mathrm{ppm,} \mathrm{K} \mathrm{0,2} \mathrm{cmol(+)/kg,}$ dan $\mathrm{pH}$ 4-8. Menunjukan bahwa tanah bekas ini mengandung unsur hara yang cukup tinggi. Berdasarkan penelitian Saputri, Milyati (2018) pupuk darah sapi ini diaplikasikan dengan macam-macam bioaktivator Mikoriza ialah nasi basi, rumen sapi, dan ragi pada tanaman kedelai.

Berdasarkan uraian diatas maka perlu dilakukan penelitian tentang "Pengaruh Tanah Bekas Macam-macam Bioaktivator Dan Mikoriza Serta Kombinasi Pupuk Anorganik Terhadap Pertumbuhan Dan Hasil Tanaman Kedelai (Glycine max L.Merril).

\section{BAB II}

\section{TINJAUAN PUSTAKA}

\subsection{Kacang Kedelai}

Awalnya, kedelai dikenal dengan beberapa nama botani, yaitu Glycine soja dan Soja max. Namun pada tahun 1948 telah disepakati bahwa nama botani yang dapat diterima dalam istilah ilmiah, yaitu Glycine max (L.) Merill. Tanaman kedelai berupa tanaman semusim, berbentuk semak pendek setinggi $30-100 \mathrm{~cm}$, bercabang sedikit maupun banyak tergantung kultivar dan lingkungan hidup. kedelai yang telah dibudidayakan tersebut merupakan tanaman liar yang tumbuh merambat yang buahnya berbentuk polong dan bijinya bulat lonjong. Tanaman kedelai ini dibudidayakan di lahan sawah maupun lahan kering (ladang) (Suprapti, 2003).

Kedelai dapat diandalkan untuk mengatasi kekurangan protein dalam menu makanan rakyat Indonesia. Kedelai diproses menjadi bahan makanan yang dapat dilakukan dengan berbagai cara, diantaranya dengan penghancuran, perebusan, peragian, fermentasi dan pengasaman, sehingga menghasilkan produk tahu, kembang tahu, susu, kecap dan produk lainnya (Nugroho, 2007). Kedelai mendapat perhatian besar di seluruh dunia karena berbagai keunggulan Kedelai mendapat perhatian besar di seluruh dunia karena berbagai keunggulan lain yang dimilikinya diantaranya memilki adaptibilitas agronomis yang tinggi, dapat hidup di daerah tropis dan subtropis, juga di daerah dengan tanah dan iklim yang memungkinkan tanaman pangan lainnya untuk tumbuhnya, serta memiliki kandungangizi yang relatif tinggi dan lengkap sebagaimana terangkum dalam tabel (Suprapti, 2003).

Menurut (Adisarwanto 2005), sistematika tumbuhan tanaman kedelai adalah sebagai berikut:

Klasifikasi tanaman kedelai adalah sebagai berikut :

Kingdom : Plantae

Divisi : Spermatophyta

Sub-divisi : Angiospermae

Kelas : : Dicotyledonae

Ordo : Polypetales

Famili : Leguminosea

Sub-famili : Papilionoideae

Genus : Glycine

Species : Glycine max 
Tipe pertumbuhan batang dapat dibedakan menjadi terbatas (determinet), tidak terbatas (indeterminet), dan setengah terbatas (semideterminet). Tipe terbatas memiliki ciri khas berbunga serentak dan mengakhiri pertumbuhan meninggi jika sudah berbunga. Tipe tidak terbatas memiliki ciri berbunga secara bertahap dari bawah keatas (Pitojo, 2003).

\subsection{Morfologi Tanaman Kedelai}

Secara morfologi, pertumbuhan tanaman kedelai mencakup organ - organ seperti, akar, batang, daun, bunga, polong, dan biji.

\subsubsection{Akar dan Bintil Akar}

Sistem perakaran tanaman kedelai terdiri dari akar tunggang. Akar sekunder yang tumbuh dari akar tunggang, serta akar cabang yang tumbuh dari akar sekunder. Pada kondisi yang sangat optimal, akar tunggang kedelai dapat tumbuh hingga kedalaman 2 meter. Perkembangan akar tanaman kedelai dipengaruhi oleh beberapa faktor seperti, penyiapan lahan, tekstur tanah, kondisi fisik, dan kimia tanah, serta kadar air tanah. Jika kelembapan tanah turun akar akan berkembang lebih dalam agar dapat menyerap unsur hara dan air. Semakin banyak bintil akar, maka akan membantu dalam menyediakan unsur hara nitrogen. Unsur hara nitrogen sangat dibutuhkan oleh tanaman karena membantu proses pertumbuhan pada akar, batang dan daun (Sari, Aini dan Setyobudi, 2015). Bintil akar sangat berperan dalam proses fiksasi N2 yang sangat dibutuhkan tanaman kedelai untuk kelanjutan pertumbuhannya.

\subsubsection{Batang dan Cabang}

Tanaman kedelai memiliki batang yang berukuran tinggi berkisar $30-100 \mathrm{~cm}$ bahkan lebih. Pada setiap batang kedelai terdapat 3 sampai 6 cabang, dan apabila jarak tanam terlalu rapat cabang menjadi berkurang, atau tidak bercabang sama sekali. Jumlah buku pada batang akan bertambah sesuai pertumbuhan umur tanaman, pada kondisi normal jumlah buku dapat berkisar antara 15 - 20 buku dengan jarak antar buku berkisar antara $2-9 \mathrm{~cm}$. Jumlah cabang tergantung dari varietas dan kondisi tanah, tetapi ada juga varietas kedelai yang tidak bercabang. Jumlah batang bisa menjadi banyak bila penanaman dirapatkan dari 250.000 tanaman/hetar menjadi 500.000 tanaman/hektar (Padjar, 2010).

\subsubsection{Daun}

Bentuk daun tanaman kedelai bervariasi yakni antara oval dan lanceolate, daun kedelai biasa disebut dengan tanaman berdaun lebar (broad leaf) dan berdaun sempit (narrow leaf). Ada dua fase pada tanaman kedelai mengenai daun, fase kotiledon yang tumbuh saat tanaman masih berkecambah dan daun bertangkai tiga (trifioloate leaves) yang tumbuh setelah masa pertumbuhan. Daun kedelai merupakan tanaman majemuk yang terdiri dari tiga helai anak daun dan umumnya berwarna hijau muda atau hijau kekuning-kuningan, pada saat sudah tua daun-daunnya akan rontok. Umumnya daerah yang mempunyai tingkat kesuburan tanah tinggi sangat cocok untuk varietas kedelai yang mempunyai bentuk daun lebar. Daun mempunyai stomata antara 190$320 \mathrm{buah} / \mathrm{m}^{2}$ (Irwan, 2006).

\subsubsection{Bunga}

Bunga tanaman kedelai adalah bunga sempurna, artinya setiap bunga mempunyai alat jantan dan betina. Tanaman kedelai di Indonesia yang mempunyai panjanghari ratarata sekitar 12 jam dan suhu udara yang tinggi $\left(>30{ }^{\circ} \mathrm{C}\right)$, sebagian besar mulai berbunga pada umur antara 5-7 minggu. Pada suhu tinggi dan kelembaban rendah, jumlah sinar matahari yang jatuh pada ketiak tangkai daun lebih banyak. Hal ini akan merangsang pembentukan bunga. Tangkai bunga umumnya tumbuh dari ketiak tangkai daun yang diberi nama rasim. Jumlah bunga pada setiap tangkai daun sangat beragam, 2-25 bunga, tergantung dari kondisi lingkungan tumbuh dan varietas kedelai. Bunga pertama yang terbentuk umumnya pada buku kelima, keenam, atau pada buku yang lebih tinggi. Warna bunga yang umum pada varietas kedelai ada dua, yaitu putih dan ungu. Tidak semua bunga dapat menjadi polong walaupun 
terjadi penyerbukan secara sempurna, sekitar $60 \%$ bunga rontok sebelum membentuk polong (Anggi, 2018).

\subsubsection{Polong}

Polong kedelai pertama berbentuk sekitar 7-10 hari setelah munculnya bunga pertama. Panjang polong muda sekitar $1 \mathrm{~cm}$, jumlah polong yang terbentuk pada setiap ketiak tangkai daun sangat beragam, antara 110 buah dalam setiap kelompok. Pada setiap tanaman, jumlah polong dapat mencapai lebih dari 50, bahkan ratusan (Gumilar, Ginting, Silitinga, 2013). Polong kedelai berbentuk pipih dan lebar yang panjangnya $5 \mathrm{~cm}$, warna polong kedelai bervariasi, bergantung pada varietasnya. Ada yang berwarnah cokelat muda, cokelat, cokelat kehitaman, putih dan kuning kecokelatan (warna jerami).Buah kedelai berbentuk polong, setiap tanaman mampu menghasilkan 100-250 polong.Jumlah biji dalam polong bervariasi antara $1-4$ buah, bergantung pada panjang polong. Polong kedelai bersusun bersegmen - segmen yang berisi biji.

\subsubsection{Biji}

Ukuran dan warna biji kedelai juga tidak sama, tetapi sebagian besar berwarna kuning dengan ukuran biji kedelai yang dapat digolongkan dalam tiga kelompok, mulai dari kecil (7-9 g/100 biji), sedang (10-13 g/100 biji), dan besar (>13 g/100 biji). Polong kedelai pertama kali muncul sekitar 10-14 hari setelah bunga pertama muncul. Warna polong yang baru tumbuh berwarna hijau dan selanjutnya akan berubah menjadi kuning atau cokelat pada saat dipanen (Fachrudin, 2000). Bentuk biji bervariasi, tergantung pada varietas tanaman, yaitu bulat, agak pipih, dan bulat telur.Biji kedelai terbagi menjadi duabagian utama,yaitu kulit biji dan janin (embrio). Pada kulit biji terdapat bagian yang disebut pusar (hilum) yang berwarna coklat, hitam, atau putih. Pada ujung hilum terdapat mikrofil, berupa lubang kecil yang terbentuk pada saat proses pembentukan biji.

\subsection{Kandungan Gizi Kedelai}

Kedelai sangat berkhasiat bagi pertumbuhan dan menjaga kondisi sel-sel tubuh. Kandungan gizi dari bahan olahan yang berasal dari kacang kedelai (per 100 gr) yaitu Setiap 100 gr kedelai mengandung 330 kalori, 35 gr protein, 18 g lemak, 35 gr karbohidrat, 8 gr air, 227 mgr kalsium, 585 mgr Fosfor, 8 gr Besi, 110 hari S.I Vitamin A dan 1 mgr Vitamin B1. (Amanda, 2008).

\subsection{Syarat Tumbuh}

Di Indonesia kedelai dapat tumbuh dan berproduksi dengan baik. Tanaman kedelai juga berproduksi pada dataran rendah sampai $900 \mathrm{~m} \mathrm{dpl}$, dan mampu beradaptasi didataran tinggi sampai lebih kurang $1.200 \mathrm{~m}$ dpl (Anggi, 2018). Syarat tumbuh tanaman kedelai meliputi iklim, suhu, kelembapan, curah hujan, cahaya matahari, dan tanah.

\subsubsection{Iklim}

Pada tanaman kedelai pertumbuhan terbaik terjadi pada temperatur antara 25-27 ${ }^{\circ} \mathrm{C}$, dengan penyinaran penuh (minimal 10 jam/hari). Iklim curah hujan $100-200$ mm/ bulan, kelembapan 75-90 \%, Suhu 21-34 ${ }^{\circ} \mathrm{C}$. Optimum $23-24{ }^{\circ} \mathrm{C}$, dan penyinaran $10-12$ jam perhari (Adisarwanto, 2008). Komponen yang ada di dalam faktor iklim antara lain suhu, kelembapan udara dan curah hujan.

\subsubsection{Suhu}

Untuk pertumbuhan tanaman kedelai suhu udara yang sesuai berkisar antara $25{ }^{\circ} \mathrm{C}$ $-28{ }^{\circ} \mathrm{C}$. Berdasarkan hasil penelitian (Sutardi, 2011) bahwa daya tumbuh terhambat disebabkan suhu tanah yang rendah $\left(<15^{\circ} \mathrm{C}\right)$, proses perkecambahan menjadi sangat lambat, bisa mencapai 2 minggu. Hal ini dikarenakan perkecambahan biji tertekan pada kondisi kelembaban tanah tinggi. Sementara pada suhu tinggi $\left(>30{ }^{0} \mathrm{C}\right)$, banyak biji yang mati akibat respirasi air dari dalam biji yang terlalu cepat.

\subsubsection{Kelembaban}

Kelembapan udara yang optimal untuk pertumbuhan tanaman kedelai berkisar 7590\%. (Adisarwanto, 2014). Tanaman kedelai sebagian besar tumbuh di daerah yang beriklim tropis dan subtropis. Sebagai barometer iklim yang cocok bagi kedelai adalah bila cocok bagi tanaman jagung. 
Kelembaban udara berpengaruh langsung terhadap proses pemasakan biji kedelai karena semakin tinggi kelembapan, proses pemasakan polong akan semakin cepat sehingga proses pembentukan biji menjadi kurang optimal.

\subsubsection{Curah Hujan}

Curah hujan yang terlalu tinggi dapat menyebabkan polong busuk dan pertumbuhan kedelai menjadi terhambat. Curah hujan yang optimum untuk tanaman kedelai berkisar 200 $\mathrm{mm}$ per bulan (Sumarno dan Manshuri, 2007).

\subsubsection{Cahaya Matahari}

Penyinaran matahari yang terang dan cukup dapat mempengaruhi pertumbuhan kedelai. Lama penyinaran matahari pada tanaman kedelai penyinaran yang optimal adalah 10- 12 jam (Taufiq dan Sundari, 2012).

\subsubsection{Tanah}

Pada dasarnya kedelai menghendaki kondisi tanah yang tidak terlalu basah, tetapi air tetap tersedia. Toleransi keasaman tanah sebagai syarat tumbuh bagi kedelai adalah $\mathrm{pH}$ 5,8-7,0 yeyapi pada $\mathrm{pH} 4,5$ pun kedelai dapat tumbuh. Pada $\mathrm{pH}$ kurang 5,5 pertumbuhannya sangat terlambat karena keracunan alumunium (Padjar, 2010).

\subsection{Pupuk Anorganik}

Pupuk adalah suatu bahan yang mengandung satu atau lebih unsur hara atau nutrisi bagi tanaman untuk menopang tumbuh dan berkembangnya tanaman. Pada umumnya pupuk anorganik dibuat oleh pabrik secara kimia. Pupuk anorganik biasanya memiliki kandungan hara yang cukup tinggi dan efek yang ditimbulkan jika diaplikasikan ke tanaman dapat cepat terlihat. Unsur yang paling dominan dalam pupuk anorganik yaitu unsur N, P, K. Hal ini sejalan dengan pendapat Sutejo (2002) bahwa pemberian pupuk anorganik ke dalam tanah dapat menambah ketersediaan hara yang cepat bagi tanaman.
Dosis pupuk yang direkomendasikan secara umum, dosis pupuk Urea sebanyak $25 \mathrm{~kg} / \mathrm{ha}$, Pupuk SP36 $100 \mathrm{~kg} / \mathrm{ha}$, dan pupuk KCL sebanyak $50 \mathrm{~kg} / \mathrm{ha}$ (Atman, 2014).

\subsection{Tepung Darah Sapi}

Darah adalah cairan yang terdapat pada semua makhluk hidup (kecuali tumbuhan) tingkat tinggi yang berfungsi mengirimkan zat-zat dan oksigen yang dibutuhkan oleh jaringan tubuh, mengangkut bahan-bahan kimia hasil metabolisme, dan juga sebagai pertahanan tubuh terhadap virus atau bakteri (http://id.wikipedia.org, 2013).

Darah Sapi mengandung energi sebesar 104 kilokalori, protein 21,9 gram, karbohidrat 0 gram, lemak 1,1 gram, kalsium 7 miligram, fosfor 24 miligram, dan zat besi 1 miligram. Selain itu di dalam Darah Sapi juga terkandung vitamin A sebanyak 50 IU, vitamin B1 0 miligram dan vitamin C 0 miligram. Dari hasil analisis, Pupuk Cair dari Limbah Darah Sapi ini mengandung Corganik sebesar 0,2 \%, Nitrogen (N) sebesar $5,5 \%$, Phospor sebesar 37,70 \% dan Kalium sebesar 0,12\% (Fitri dkk, 2012).

Menurut dinas peternakan dan perikanan di Provinsi Bengkulu (2014), dalam sehari pemotongan hewan dilakukan sebanyak 10-15 ekor, di RPH (Rumah Pemotongan Hewan) Padang Serai Bengkulu darah sapi hasil pemotongan langsung dibuang tanpa diolah terlebih dahulu sehingga berpotensi menjadi limbah yang dapat mengganggu lingkungan.

\begin{tabular}{|c|c|c|}
\hline $\mathrm{N}_{0}$ & Kandungan Unsur Hara & Jumlah Unsur Haranya \\
\hline l & Nitrogen & $14,9 \%$ \\
\hline 2 & Fosfat & $0,45 \%$ \\
\hline 3 & Kalium & $0,59 \%$ \\
\hline 4 & Calium & $615 \mathrm{mg} k \mathrm{~kg}$ \\
\hline 5 & Magnesium (Mg) & $405 \mathrm{mg} / \mathrm{kg}$ \\
\hline 6 & Cupri (Cu) & $10 \mathrm{mg} / \mathrm{kg}$ \\
\hline 7 & $\operatorname{Besi}(\mathrm{Fe})$ & $0,26 \% \mathrm{~s}$ \\
\hline 8 & Seng $(Z n)$ & $117 \mathrm{mg} / \mathrm{kg}$ \\
\hline 9 & Manggan (Mn) & $11 \mathrm{mg} \mathrm{kg}$ \\
\hline
\end{tabular}

\subsection{Mikoriza}

Peningkatan produksi kedelai sangat diinginkan oleh para petani oleh sebab itu, dengan adanya upaya penambahan fungi Mikoriza pada tanaman kedelai dapat membantu dalam peningkatkan produksi 
kedelai. Hal ini sesuai dengan penelitian yang dilakukan oleh Hakiki,dkk (2013) bahwa pemberian Mikoriza 10g per tanaman membeikan pengaruh yang lebih baik yaitu dapat meningkatkan hasil produksi pada tanaman kedelai.

Fungsi Mikoriza juga dapat dikatakan sebagai biofertilizer untuk tanaman pertanian, secara langsung yang berfungsi sebagai meningkatkan serapam air, hara dan perlindungan tanaman terhadap patogen tanah, dan secara tidak langsung dengan perbaikan struktur tanah dan peningkatan kelarutan hara (Subiksa, 2002).

Secara umum Mikoriza mempunyai fungsi bagi tanaman dimana Mikoriza memiliki hormon zat perangsang tumbuh seperti giberelin, auksin, sitokinin yang dapat mempercepat pertumbuhan pada tanaman, dapat mengurangi stres pada tanaman dalam kondisi kekurangan air, karena akar tanaman yang akan dibantu oleh Mikoriza dalam penyerapan air sehingga akar memiliki jangkauan lebih panjang, dan Mikoriza dapat meningkatkan aerasi dalam tanah karena kemampuan Mikoriza dalam memperbaiki agregat tanah (Sakethi, 2018).

\subsection{Bioaktivator}

\begin{abstract}
Menurut Budiyanto (2013) bioaktivator dapat dibuat sendiri dengan mudah yaitu dengan menggunakan bahan yang mudah ditemukan dan memiliki harga murah, karena dapat memanfaatkan limbah dan sampah organik. Bioaktivator itu sendiri bukanlah pupuk atau zat perangsang tumbuh lainnya, akan tetapi merupakan bahan yang memiliki kandungan mikroorganisme yang aktif untuk membantu mengurai sampah dan limbah organik untuk meningkatkan kualitas bahan organik sebagai pupuk, sehingga dapat meningkatkan unsur hara yang terdapat didalam tanah untuk dapat menyediakan nutrisi bagi pertumbuhan tanaman.
\end{abstract}

Adapun mikroorganisme didalam bioaktivator memiliki sifat alami, yaitu mikroorganime lactobacillus, decomposer, ragi dll, adapula kandungan mikroorganisme yang mengguntungkan yaitu bakteri penambat $\mathrm{N}$, pelarut Pospat dll.

\subsection{Tanah Bekas Bioaktivator dan Mikoriza}

Hasil analisis yang dilakukan di laboratorium tanag Balai Penelitian Tanaman Pangan (BPTP) Bengkulu 2019 menunjukan bahwa tanah yang digunakan dari penelitian Juliana, Milyati (2018) yang menggunakan tepung darah sapi dengan macam-macam bioaktivator Mikoriza memiliki kandungan $\mathrm{N}$ 0,18 \%, P 44,13 ppm, K 0,63 cmol(+)/kg, dan $\mathrm{Ph}$ 4,87 (Bioaktivator Mikoriza + Nasi Basi), $\mathrm{N} \mathrm{0,20 \% ,P} \mathrm{32,93} \mathrm{ppm,} \mathrm{K} \mathrm{0,56} \mathrm{cmol(+)/kg,}$ dan $\mathrm{Ph}$ 4,76 (Bioaktivator Mikoriza + Rumen), N 0,30 \%, P 24,47 ppm, K 0,12 $\mathrm{cmol}(+) / \mathrm{kg}$ dan $\mathrm{Ph} \quad 4,86$ (Bioaktivator Mikoriza + Ragi). Jika dibandingkan dengan standar kandungan hara tanah N 0,4 \%, P 0,1 ppm, $\quad \mathrm{K} \quad 0,2 \quad \mathrm{cmol}(+) / \mathrm{kg}$, dan $\mathrm{pH}$ 4-8. Menunjukan bahwa tanah bekas ini mengandung unsur hara yang cukup tinggi.

Berdasarkan penelitian tersebut aplikasi darah sapi dengan macam-macam bioaktivator Mikoriza menggunakan nasi basi, rumen sapi dan ragi pada tanaman kedelai. Tanah yang digunakan sebagai media tanam masih banyak sisa unsur hara yang dapat digunakan kembali sebagai media tanam dengan tujuan untuk mengefisiensi penggunaan pupuk anorganik. Tanah bekas ini digunakan untuk merangsang bintil akar tanaman kedelai yang diberi bioaktivator bersifat organik.

\begin{tabular}{|c|c|c|c|}
\hline \multirow{2}{*}{ Tabel 2. Hasil Analisis Tanah Awal Kandungan Hara Tanah Bekas } \\
\hline \multirow{3}{*}{ Uraian } & \multicolumn{3}{|c|}{ Tanah Bekas Macam Mikoriza } \\
\cline { 2 - 4 } & Nasi Basi & Rumen Sapi & Ragi \\
\hline Kadar air & 1,55 & 2,72 & 3,05 \\
pH H² & 4,87 & 4,76 & 4,86 \\
KCl & 3,92 & 3,96 & 3,96 \\
Bahan Organik N (\%) & 0,18 & 0,20 & 0,30 \\
P. bray I ppm & 44,13 & 32,93 & 24,47 \\
Ntk. K-dd cmol (+) kg & 0,63 & 0,56 & 0,12 \\
\hline Sumber: (BPTP Bengkulu, 2019) & & \\
\hline
\end{tabular}




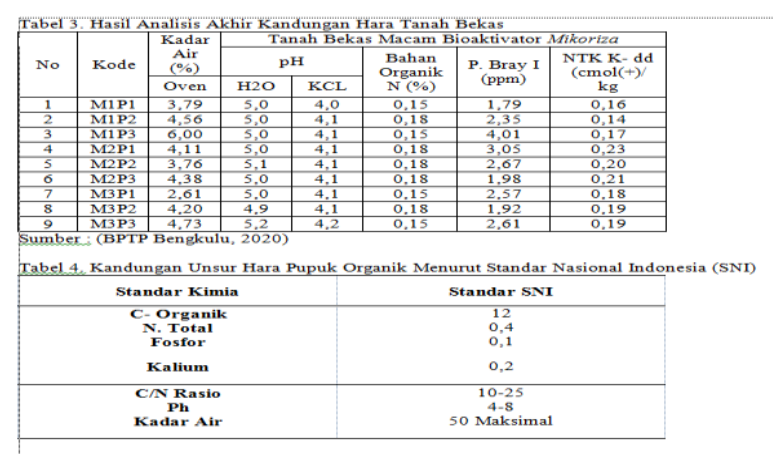

BAB III

\section{METODOLOGI PENELITIAN}

\subsection{Tempat dan Waktu}

Penelitian telah dilaksanakan di Jl. Danau Raya No.59, Panorama, Singaran Pati, Kota Bengkulu pada ketinggian tempat 30 meter di atas permukaan laut, yang dimulai dari bulan Juli sampai Oktober 2019.

\subsection{Alat dan Bahan}

\subsubsection{Alat}

Alat yang akan digunakan adalah cangkul, ember, meteran, gunting, pisau, timbangan, selang, hansprayer, alat tulis, penggaris, kamera.

\subsubsection{Bahan}

Bahan yang akan digunakan adalah air, benih kedelai varietas Demas 1 yang diperoleh dari Balai Kacang-kacangan dan Umbi-umbian, Malang. Tanah bekas aplikasi bioaktivator dan Mikoriza, Pupuk Urea, Sp$36, \mathrm{KCl}$, polybag ukuran $10 \mathrm{~kg}$.

\subsection{Metodologi Penelitian}

Penelitian ini lakukan dengan menggunakan rancangan acak lengkap (RAL) disusun secara faktorial. Terdiri dari 2 faktorial yaitu:

Faktor pertama adalah tanah bekas macammacam bioaktivator dan Mikoriza yaitu :

M1= Bioaktivator Ragi + Mikoriza

M2 = Bioaktivator Nasi Basi + Mikoriza

M3 = Bioaktivator Rumen Sapi + Mikoriza
Faktor kedua adalah kombinasi pupuk anorganik:

$\mathrm{P} 1=12,5 \mathrm{~kg}$ Urea $/ \mathrm{ha}+100 \mathrm{~kg} \mathrm{SP} 36 / \mathrm{ha}+50 \mathrm{~kg}$ $\mathrm{KCL} / \mathrm{ha}$

$\mathrm{P} 2=25 \mathrm{~kg}$ Urea $/ \mathrm{ha}+50 \mathrm{~kg} \mathrm{SP} 36 / \mathrm{ha}+50 \mathrm{~kg}$ $\mathrm{KCL} / \mathrm{ha}$

P3 = $25 \mathrm{~kg}$ Urea/ha +100 kg SP36/ha $+25 \mathrm{~kg}$ $\mathrm{KCL} / \mathrm{ha}$

Terdapat 9 kombinasi perlakuan, diulang sebanyak 3 kali sehingga diperoleh 27 unit percobaan. Setiap unit percobaan terdapat 2 tanaman, sehingga diperoleh 54 tanaman.

\section{Model Ral}

Model linier yang digunakan dalam percobaan rancangan acak lengkap ini dapat ditulis sebagai berikut :

Yijk $=\mu+\alpha \mathbf{i}+\beta j+(\alpha \beta) \mathbf{i j}+\varepsilon \mathbf{i j k}$

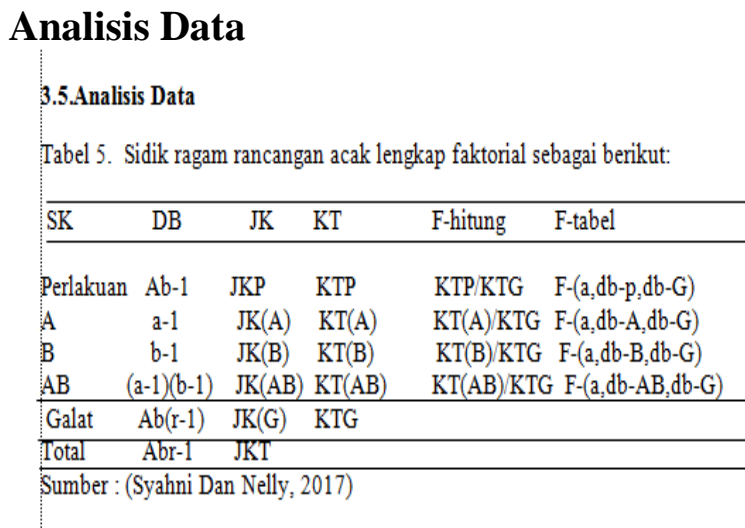

Data yang diperoleh akan dianalisis keragaman menurut rancangan yang digunakan. Apabila dalam uji $\mathrm{F}$ terdapat pengaruh nyata, dilanjutkan di uji lanjut dengan menggunakan uji jarak berganda/Duncan Multiple Range Test (DMRT) pada taraf $5 \%$.

\section{Pelaksanaan Penelitian}

Analisis tanah

Analisis bertujuan untuk mengetahui karakteristik tanah yaitu sifat kimia yang meliputi $\mathrm{pH}$ tanah, kandungan nitrogen, kandungan fosfor, kandungan karbon organik sebelum dilakukan percobaan. Dilakukan pada awal percobaan di BPTP Bengkulu. 


\section{Mempersiapkan media tanam}

Sebelum mulai peletakan polibag dilahan lakukan terlebih dahulu membersihkan lahan dari tanaman yang dapat mengganggu nantinya, serta bersihkan dari sampah-sampah lainnya. Setelah lahan dibersihkan, isi polibag yang berukuran $10 \mathrm{~kg}$ dengan tanah bekas bioaktivator Mikoriza. Susun polybag kelahan yang telah dibersihkan sesuai dengan denah percobaan.

\section{Penanaman benih}

Benih kedelai di tanam kedalam polibag yang telah berisikan tanah bekas. Tanah diberi lubang tengahnya dengan kedalaman $2 \mathrm{~cm}$ dengan masing-masing satu polibag berisikan 2 benih kedelai.

\section{Pemupukan}

Pemupukan dilakukan dua kali, pada awal penanaman sebanyak setengah dari dosis masing-masing perlakuan dan setengahnya diberikan saat tanaman berumur 30 HST. Cara pengaplikasian dengan cara dibuat larikan pada sela-sela tanaman kedelai.

\section{Pemeliharaan tanaman kedelai}

Tanaman di pelihara dengan dilakukannya penyiraman secara rutin, saat pagi hari dan sore hari saat cuaca panas. Lakukan penjarangan pada saat tanaman berumur satu minggu, dengan mencabut tanaman yang tidak perlu bertujuan untuk mengurangi tanaman dan pilih tanaman yang paling baik pertumbuhannya. Agar tidak terjadi perbedaan pertumbuhan yang mencolok antara tanaman asli dan hasil sulaman dilakukan penyulaman pada umur 2 minggu setelah tanam. Untuk menghindari persaingan antara gulma dan tanaman maka perlu dilakukannya penyiangan. Dilakukan pada setiap minggu saat gulma terlihat tumbuh disekitar tanaman kedelai dengan cara mencabut langsung tanaman pengganggu menggunakan tangan. Pada perlindungan tanaman dari hama dan penyakit dapat dilakukan penyemprotan dengan menggunakan biopestisida yang berasal dari tanaman serai.

\section{Parameter yang diamati \\ Tinggi Tanaman $(\mathrm{cm})$}

Tinggi tanaman dapat diukur dengan menggunakan mistar/meteran (cm), dari permukaan tanah sampai dengan ke titik apikal. Pengukuran ini dilakukan 2 minggu sekali yaitu pada umur 14 HST, 28 HST, 42 HST, dan 56 HST.

\section{Jumlah Daun (helai)}

Jumlah daun dihitung dari daun yang telah terbuka sempurna pada setiap tanaman, pengamatan ini dilakukan 2 minggu sekali pada umur 14 HST, 28 HST, 42 HST, dan 56 HST.

\section{Jumlah Cabang}

Penghitungan jumlah cabang pada setiap tanaman dilakukan 2 minggu sekali pada umur 28 HST dan 42 HST.

\section{Panjang Akar}

Untuk mengetahui panjang akar dilakukan dengan cara pembongkaran polybag tanaman diseluruh unit percobaan. Panjang akar dihitung dengan cara manual pada saat setelah panen. Disiram dengan keran air agar akar tidak putus.

\section{Berat Basah Tanaman (gr)}

Pengamatan ini dilakukan dengan cara menimbang seluruh tanaman menggunakan timbangan analitik (Digital Sartorius Bp 3100p) dilakukan pada saat setelah panen.

\section{Berat Kering Tanaman (gr)}

Pengamatan ini dilakukan dengan cara menimbang seluruh tanaman menggunakan timbangan ketika sudah dijemur sampai berat konstan pada saat setelah panen.

\section{Berat Polong Basah (gr)}

Pengamatan ini dilakukan pada saat panen. Menghitung berat polong basah dilakukan pada setiap tanaman dengan menimbang berat polong yang berisi.

\section{Berat Polong Kering (gr)}

Pengamatan ini dilakukan pada saat panen setelah dilakukan penjemuran dibawah sinar matahari hingga mencapai berat yang konstan. Menghitung berat polong kering 
dilakukan pada setiap tanaman dengan menimbang berat polong yang berisi.

\section{Jumlah Polong Isi Pertanaman (gr)}

Dilakukan pada saat setelah panen dengan menghitung total polong isi per tanaman. Sebelum dilakukan penghitungan total polong terlebih dahulu memisahkan polong dari batang tanaman.

\section{Jumlah Polong Hampa (cipo)}

Dilakukan pada saat setelah panen dengan menghitung total polong yang hampa/ tidak berisi per tanaman. Sebelum dilakukan penghitungan total polong hampa (cipo) terlebih dahulu memisahkan polong berisi dengan polong hampa (cipo).

\section{Jumlah Biji Pertanaman (Biji)}

Penghitungan ini dilakukan setelah panen dengan menghitung jumlah biji pada setiap tanaman. Adapun caranya dengan pemisahan biji yang ada pada setiap polong tanaman.

\section{Berat Biji Pertanaman (gr)}

Penimbangan berat biji kedelai ini dilakukan saat setelah panen dengan cara memisahkan biji pada polongnya.

\section{Berat 100 Biji Tanaman (gr)}

Pengamatan biji kedelai ini dilakukan dengan cara menimbang 100 biji kedelai, dengan kadar air $\pm 14 \%$ diperoleh dengan menjemur biji kedelai dibawah sinar matahari selama 2-3 hari. Penimbangan biji dilakukan hanya pada tanaman sampel.

\section{BAB IV}

\section{HASIL DAN PEMBAHASAN}

\subsection{Hasil}

Hasil analisis keragaman untuk masing-masing faktor dan interaksinya terhadap semua peubah yang diamati dapat dilihat dari Tabel 4.

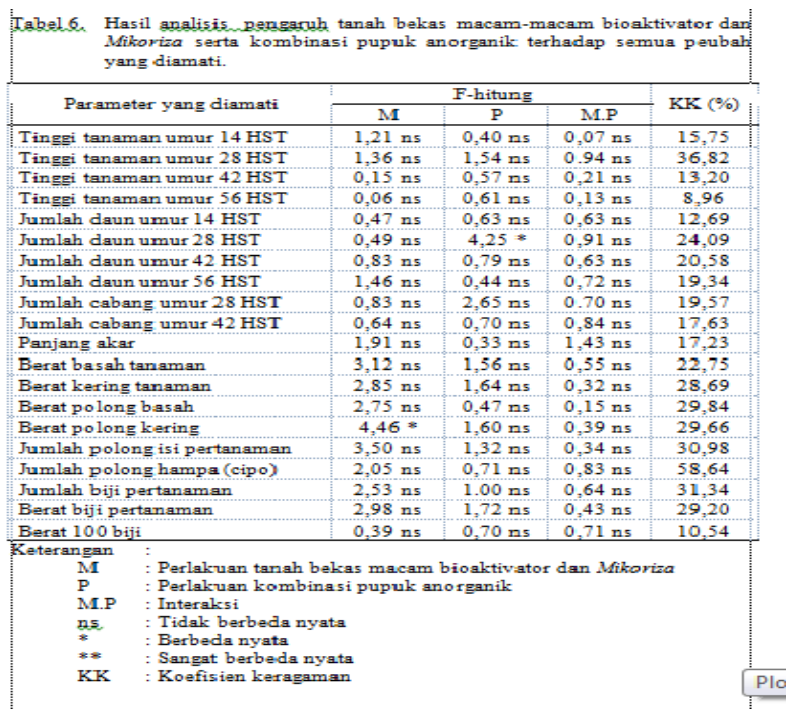

\subsubsection{Tinggi Tanaman}

Hasil pengamatan tinggi tanaman kedelai rata-rata dapat dilihat pada Lampiran 3, 5, 7 dan 9. Hasil analisis keragaman menunjukan bahwa perlakuan tanah bekas macam-macam bioaktivator dan Mikoriza dan kombinasi pupuk anorganik tidak berpengaruh nyata terhadap tinggi tanaman. Interaksi antara keduanya juga tidak menunjukkan pengaruh yang nyata terhadap tinggi tananam.

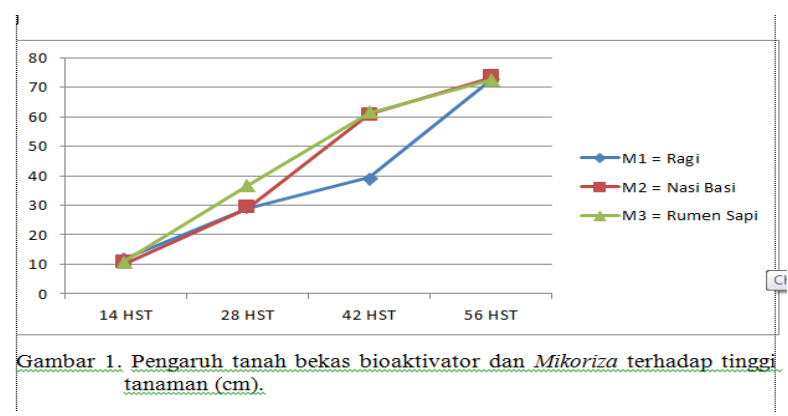

Bahwa perlakuan tanah bekas macam-macam bioaktivator dan Mikoriza tidak menunjukkan pengaruh nyata terhadap tinggi tanaman.

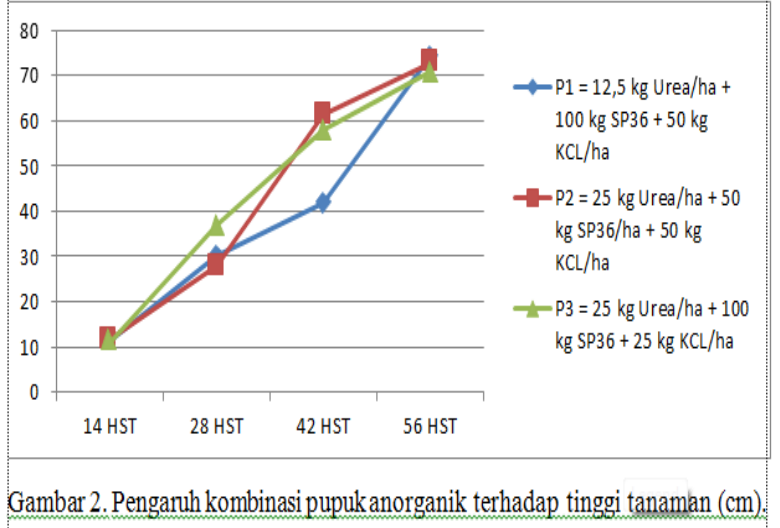


Bahwa perlakuan kombinasi pupuk anorganik tidak menunjukan pengaruh nyata terhadap tinggi tanaman.

\subsubsection{Jumlah daun}

Hasil pengamatan jumlah daun tanaman kedelai rata-rata dapat dilihat pada Lampiran 11, 13, 15 dan 17. Hasil analisis keragaman pada Lampiran 14 menunjukkan bahwa perlakuan kombinasi pupuk anorganik berpengaruh nyata, sedangkan perlakuan tanah bekas macam-macam bioaktivator dan Mikoriza dan interaksi keduanya tidak berpengaruh nyata terhadap jumlah daun. Hasil uji DMRT kombinasi pupuk anorganik dapat dilihat pada tabel dibawah ini:

\begin{tabular}{|c|c|c|c|c|}
\hline \multirow{2}{*}{ Tanah Bekas } & \multicolumn{3}{|c|}{ Kombinasi Pupuk Anorganik } & \multirow{2}{*}{$\begin{array}{c}\text { Pengaruh } \\
\text { Utama Tanah } \\
\text { Bekas }\end{array}$} \\
\hline & $\mathrm{P} 1$ & $\mathrm{P} 2$ & $\mathrm{P} 3$ & \\
\hline M1 (Ragi) & 31,00 & 24,00 & 20,00 & 25,00 \\
\hline M2 (Nasi Basi) & 30,00 & 24,00 & 28,00 & 27,33 \\
\hline M3 (Rumen Sapi) & 30,00 & 18,00 & 36,00 & 28,00 \\
\hline $\begin{array}{l}\text { Pengaruh Utama } \\
\text { Pupuk Anorganik }\end{array}$ & 30,33 a & $22,00 \mathrm{~b}$ & $28,00 \mathrm{ab}$ & \\
\hline
\end{tabular}

Berdasarkan tabel diatas memperlihatkan bahwa pengaruh kombinasi pupuk anorganik P1 ( $1 / 2$ Urea + SP36 + KCL) berbeda nyata dengan P2 (Urea $+1 / 2$ SP36 + KCL) pada jumlah daun tanaman kedelai. Namun pengaruh kombinasi pupuk anorganik P3 ( Urea + SP36 + 1/2 KCL) tidak berbeda nyata dengan P1 ( $1 / 2$ Urea + SP36 + KCL) dan P2 ( Urea $+1 / 2$ SP36 + KCL).

\subsubsection{Jumlah cabang}

Hasil pengamatan dan analisis keragaman terhadap rata-rata jumlah cabang tanaman kedelai dapat dilihat pada Lampiran 19 dan 21. Menunjukkan bahwa perlakuan tanah bekas macam-macam bioaktivator dan Mikoriza dan kombinasi pupuk anorganik tidak berpengaruh nyata terhadap jumlah cabang. Interaksi keduanya juga tidak menunjukkan perngaruh yang nyata terhadap jumlah cabang.

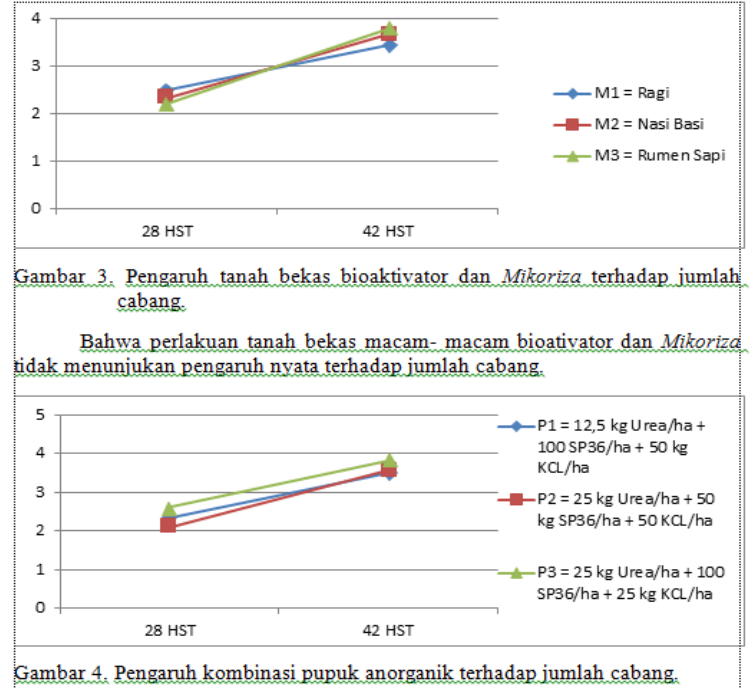

Bahwa perlakuan kombinasi pupuk anorganik tidak menunjukan pengaruh nyata terhadap jumlah cabang.

\subsubsection{Panjang akar}

Hasil pengamatan dan analisis keragaman terhadap rata-rata panjang akar tanaman kedelai dapat dilihat pada Lampiran 23. Menunjukkan bahwa perlakuan tanah bekas macam-macam bioaktivator dan Mikoriza dengan kombinasi pupuk anorganik serta interaksi keduanya tidak berpengaruh nyata terhadap panjang akar, seperti terlihat pada tabel dibawah ini:

\begin{tabular}{|c|c|c|c|c|}
\hline \multicolumn{5}{|l|}{ Tabel 8. Panjang Akar } \\
\hline \multirow{2}{*}{ Tanah Bekas } & \multicolumn{3}{|c|}{ Kombimasi Pupuk Anorganilk } & \multirow{2}{*}{$\begin{array}{c}\text { Pengaruh } \\
\text { Utama Tana } \\
\text { Bekas } \\
\end{array}$} \\
\hline & $\mathrm{Pl}$ & P2 & P3 & \\
\hline M1 (Ragi) & 45,47 & 46,15 & 40,30 & 43,97 \\
\hline M2 (Nasi Basi) & 32,83 & 41,67 & 38,13 & 37,54 \\
\hline M3 (Rumen Sapi) & 28,97 & 36,53 & 45,60 & 37,03 \\
\hline $\begin{array}{l}\text { Penganuh Utama Pupuk } \\
\text { Anorganilk } \\
\end{array}$ & 35,76 & 41,45 & 41,34 & 39,52 \\
\hline
\end{tabular}

\subsubsection{Berat basah tanaman}

Hasil pengamatan rata-rata berat basah tanaman dapat dilihat pada Lampiran 25. Hasil analisis keragaman menunjukan bahwa perlakuan tanah bekas macam-macam bioaktivator dan Mikoriza dengan kombinasi pupuk anorganik dan interaksi antara kedua perlakuan tidak berbeda nyata, seperti terlihat pada tabel dibawah ini: 


\begin{tabular}{|c|c|c|c|c|}
\hline \multicolumn{5}{|c|}{ Tabel 9. Berat Basah Tanaman } \\
\hline \multirow{2}{*}{ Tanah Bekas } & \multicolumn{3}{|c|}{$\begin{array}{l}\text { Kombinasi Pupuk } \\
\text { Anorganik }\end{array}$} & \multirow{2}{*}{$\begin{array}{c}\text { Pengaruh Utama } \\
\text { Tanah Bekas }\end{array}$} \\
\hline & P1 & $\mathrm{P} 2$ & P3 & \\
\hline M1 (Ragi) & 46,33 & 42,67 & 49,50 & 46,17 \\
\hline M2 (Nasi Basi) & 37,00 & 37,50 & 39,67 & 38,06 \\
\hline M3 (Rumen Sapi) & 42,17 & 47,50 & 25,00 & 38,22 \\
\hline $\begin{array}{l}\text { Pengaruh Utama Pupuk } \\
\text { Anorganik }\end{array}$ & 41,83 & 42,56 & 38,06 & 40,82 \\
\hline
\end{tabular}

\subsubsection{Berat Kering Tanaman}

Hasil pengamatan rata-rata berat kering tanaman kedelai dapat dilihat pada Lampiran 27. Hasil analisis keragaman menunjukan bahwa perlakuan tanah bekas macam-macam bioaktivator dan Mikoriza dengan kombinasi dosis pupuk dan interaksi antara kedua perlakuan tidak berbeda nyata, seperti terlihat pada tabel dibawah ini:

\begin{tabular}{|c|c|c|c|c|}
\hline \multirow[t]{2}{*}{ Tanah Bekas } & \multicolumn{3}{|c|}{$\begin{array}{l}\text { Kombinasi Pupuk } \\
\text { Anorganik }\end{array}$} & \multirow{2}{*}{$\begin{array}{l}\text { Pengaruh Utama } \\
\text { Tanah Bekas }\end{array}$} \\
\hline & P1 & P2 & P3 & \\
\hline M1 (Ragi) & 35,50 & 37,17 & 44,50 & 39,06 \\
\hline M2 (Nasi Basi) & 30,67 & 31,33 & 32,83 & 31,61 \\
\hline M3 (Rumen Sapi) & 36,50 & 42,33 & 52,67 & 43,83 \\
\hline $\begin{array}{l}\text { Pengaruh Utama Pupuk } \\
\text { Anorganik }\end{array}$ & 34,22 & 36,94 & 43,33 & 38,17 \\
\hline
\end{tabular}

\subsubsection{Berat Polong basah}

Hasil pengamatan berat polong basah tanaman kedelai rata-rata dapat dilihat pada Lampiran 29. Hasil analisis keragaman menunjukan bahwa perlakuan tanah bekas macam-macam bioaktivator dan Mikoriza dengan kombinasi dosis pupuk dan interaksi antara kedua perlakuan tidak berbeda nyata, seperti terlihat padatabel dibawah ini:

\begin{tabular}{|l|c|c|c|c|}
\hline \multicolumn{2}{|l|}{ Tabel 11. Berat Polong Basah } \\
\hline \multirow{2}{*}{ Tanah Bekas } & \multicolumn{2}{l|}{ Kombinasi Pupuk Anorganik } & $\begin{array}{c}\text { Pengaruh } \\
\text { Utama } \\
\text { Tanah Bekas }\end{array}$ \\
\cline { 2 - 5 } & P1 & P2 & P3 & 35,11 \\
\hline M1 (Ragi) & 34,83 & 31,17 & 39,33 & 27,89 \\
\hline M2 (Nasi Basi) & 28,17 & 31,50 & 24,00 & 43,61 \\
\hline M3 (Rumen Sapi) & 43,00 & 43,67 & 44,17 & 35,54 \\
\hline $\begin{array}{l}\text { Pengaruh Utama Pupuk } \\
\text { Anorganik }\end{array}$ & 35,33 & 35,45 & 35,83 & \\
\hline
\end{tabular}

\subsubsection{Berat polong kering}

Hasil pengamatan rata-rata berat polong kering dan pengolahan data dapat dilihat pada Lampiran 27. Hasil analisis keragaman menunjukan bahwa perlakuan tanah bekas macam-macam bioaktivator dan
Mikoriza berbeda nyata terhadap berat polong kering, sedangkan kombinasi dosis pupuk anorganik berpengaruh tidak nyata. Interaksi antara kedua perlakuan menunjukkan tidak nyata terhadap berat polong kering, seperti terlihat pada tabel dibawah ini:

\begin{tabular}{|c|c|c|c|c|}
\hline \multirow{2}{*}{ Tanah Bekas } & \multicolumn{3}{|c|}{ Kombinasi Pupuk Anorganik } & \multirow{2}{*}{$\begin{array}{c}\text { Pengaruh } \\
\text { Utama Tanah } \\
\text { Bekas }\end{array}$} \\
\hline & $\mathrm{P} 1$ & P2 & P3 & \\
\hline M1 (Ragi) & 28,00 & 22,55 & 35,17 & $28,57 \mathrm{ab}$ \\
\hline M2 (Nasi Basi) & 19,83 & 23 & 24,83 & $22,55 \mathrm{~b}$ \\
\hline M3 (Rumen Sapi) & 31,83 & 33,83 & 38,00 & $34,55 \mathrm{a}$ \\
\hline $\begin{array}{l}\text { Pengaruh Utama } \\
\text { Pupuk Anorganik }\end{array}$ & 26,55 & 26,46 & 32,67 & 28,56 \\
\hline
\end{tabular}

Dari Tabel 11 dapat dilihat bahwa perlakuan tanah bekas macam-macam bioaktivator Mikoriza M1 ( Ragi ) tidak berbeda nyata dengan M2 ( Nasi Basi ) dan M3 ( Rumen Sapi ), M2 berbeda nyata dengan M3.

\subsubsection{Jumlah Polong Isi Pertanaman}

Hasil pengamatan jumlah polong tanaman kedelai rata-rata dapat dilihat pada Lampiran 33. Hasil analisis keragaman menunjukan bahwa perlakuan tanah bekas macam-macam bioaktivator dan Mikoriza dengan kombinasi pupuk anorganik tidak berpengaruh nyata. Interaksi keduanya tidak berpengaruh nyata terhadap jumlah polong, seperti terlihat pada tabel dibawah ini:

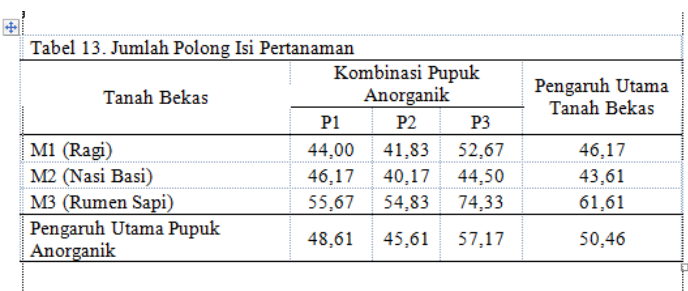

\subsubsection{Jumlah Polong Hampa (Cipo)}

Hasil pengamatan jumlah polong cipo rata-rata dapat dilihat pada Lampiran 35 . Hasil analisis keragaman menunjukan bahwa perlakuan tanah bekas macam-macam bioaktivator dan Mikoriza dengan kombinasi pupuk anorganik dan interaksi antara kedua perlakuan tidak berbeda nyata, seperti terlihat pada tabel dibawah ini: 


\begin{tabular}{|c|c|c|c|c|}
\hline \multicolumn{5}{|c|}{ Tabel 14. Jumlah Polong Hampa (Cipo) } \\
\hline \multirow{2}{*}{ Tanah Bekas } & \multicolumn{3}{|c|}{ Kombinasi Pupuk Anorganik } & \multirow{2}{*}{$\begin{array}{c}\text { Pengaruh } \\
\text { Utama Tanah } \\
\text { Bekas }\end{array}$} \\
\hline & $\mathrm{P} 1$ & $\mathrm{P} 2$ & P3 & \\
\hline M1 (Ragi) & 2,33 & 4,00 & 3,33 & 3,22 \\
\hline M2 (Nasi Basi) & 4,83 & 6,67 & 4,00 & 5,17 \\
\hline M3 (Rumen Sapi) & 4,17 & 3,67 & 5,50 & 4,45 \\
\hline $\begin{array}{l}\text { Pengaruh Utama Pupuk } \\
\text { Anorganik }\end{array}$ & 3,78 & 4,78 & 4,28 & 4,28 \\
\hline
\end{tabular}

\subsubsection{Jumlah Biji Pertanaman}

Hasil pengamatan jumlah biji rata-rata pertanaman dapat dilihat pada Lampiran 37. Hasil analisis keragaman menunjukan bahwa perlakuan tanah bekas macam-macam bioaktivator dan Mikoriza dengan kombinasi pupuk anorganik tidak berpengaruh nyata. Interaksi keduanya tidak berpengaruh nyata terhadap jumlah biji pertanaman, seperti terlihat pada tabel dibawah ini:

\begin{tabular}{|c|c|c|c|c|}
\hline \multirow[t]{2}{*}{ Tanah Bekas } & \multicolumn{3}{|c|}{$\begin{array}{l}\text { Kombinasi Pupuk } \\
\text { Anorganik }\end{array}$} & \multirow{2}{*}{$\begin{array}{c}\text { Pengaruh Utama } \\
\text { Tanah Bekas }\end{array}$} \\
\hline & P1 & $\mathrm{P} 2$ & P3 & \\
\hline M1 (Ragi) & 85,33 & 81,50 & 110,67 & 92,50 \\
\hline M2 (Nasi Basi) & 105,67 & 80,67 & 82,33 & 89,56 \\
\hline M3 (Rumen Sapi) & 111,50 & 108,00 & 140,17 & 119,89 \\
\hline $\begin{array}{l}\text { Pengaruh Utama Pupuk } \\
\text { Anorganik }\end{array}$ & 100,83 & 90,06 & 111,06 & 100,65 \\
\hline
\end{tabular}

\subsubsection{Berat Biji Pertanaman}

Hasil pengamatan berat biji pertanaman rata-rata dapat dilihat pada Lampiran 39. Hasil analisis keragaman menunjukan bahwa perlakuan tanah bekas macam-macam bioaktivator dan Mikoriza dengan kombinasi pupuk anorganik tidak berpengaruh nyata. Interaksi keduanya tidak berpengaruh nyata terhadap berat biji pertanaman, seperti terlihat pada tabel
Tabel 16. Berat Biil Pertanaman

\begin{tabular}{|c|c|c|c|c|}
\hline \multirow{2}{*}{ Tanah Bekas } & \multicolumn{3}{|c|}{$\begin{array}{c}\text { Kombinasi Pupuk } \\
\text { Anorganik }\end{array}$} & \multirow{2}{*}{$\begin{array}{c}\text { Pengaruh Utama } \\
\text { Tanah Bekas }\end{array}$} \\
\hline & $\mathrm{Pl}$ & P2 & P3 & \\
\hline M1 (Ragi) & 18,17 & 16,83 & 22,50 & 19,17 \\
\hline M2 (Nasi Basi) & 19,33 & 16,67 & 17,67 & 17,89 \\
\hline M3 (Rumen Sapi) & 24,50 & 19,83 & 28,83 & 24,39 \\
\hline $\begin{array}{l}\text { Pengaruh Utama Pupuk } \\
\text { Anorganik }\end{array}$ & 20,67 & 17,78 & 23,00 & 20,48 \\
\hline
\end{tabular}

\subsubsection{Berat 100 Biji}

Hasil pengamatan berat 100 biji ratarata dapat dilihat pada Lampiran 41. Hasil analisis keragaman menunjukan bahwa perlakuan tanah bekas macam-macam bioaktivator dan Mikoriza dengan kombinasi pupuk anorganik dan interaksi antara kedua perlakuan tidak berbeda nyata, seperti terlihat pada tabel dibawah ini:

\begin{tabular}{|c|c|c|c|c|}
\hline \multicolumn{5}{|l|}{ Tabel 17. Berat 100 Biji } \\
\hline \multirow{2}{*}{ Tanah Bekas } & \multicolumn{3}{|c|}{ Kombinasi Pupuk Anorganik } & \multirow{2}{*}{$\begin{array}{c}\text { Pengaruh } \\
\text { Utama Tanah } \\
\text { Bekas }\end{array}$} \\
\hline & $\mathrm{Pl}$ & P2 & P3 & \\
\hline M1 (Ragi) & 18,00 & 17,33 & 19,67 & 18,33 \\
\hline M2 (Nasi Basi) & 17,33 & 17,33 & 18,00 & 17,55 \\
\hline M3 (Rumen Sapi) & 19,00 & 17,33 & 17,33 & 17,89 \\
\hline $\begin{array}{l}\text { Penganuh Utama Pupuk } \\
\text { Anorganik }\end{array}$ & 18,11 & 17,33 & 18,33 & 17,92 \\
\hline
\end{tabular}

\subsection{Pembahasan}

Dari hasil analisis ragam pengaruh tanah bekas macam-macam bioaktivator dan Mikoriza dengan kombinasi pupuk anorganik terhadap pertumbuhan dan hasil tanaman kedelai (Glycine max L. Merrill) di Bengkulu pada ketinggian 34 mdpl.

Menunjukkan bahwa perlakuan tanah bekas macam-macam bioaktivator M3 (rumen sapi) + Mikoriza berpengaruh nyata terhadap berat polong kering dan tidak berpengaruh nyata terhadap tinggi tanaman, jumlah daun, jumlah cabang, panjang akar, berat basah tanaman, berat kering tanaman, berat polong basah, jumlah polong, jumlah polong cipo, jumlah biji pertanaman, berat biji pertanaman, berat 100 biji.

Hasil uji lanjut DMRT (duncan's multiple range test) menunjukkan bahwa 
perlakuan tanah bekas M3 (bioaktivator rumen sapi + Mikoriza) telah menunjukkan pengaruh nyata terhadap berat polong kering tanaman. Perlakuan tanah bekas M1 (bioaktivator ragi + Mikoriza) tidak berbeda nyata dengan M2 (bioaktivator nasi basi + Mikoriza) dan M3 (bioaktivator rumen sapi + Mikoriza). Sedangkan perlakuan tanah bekas M2 (bioaktivator nasi basi + Mikoriza) berbeda nyata dengan M3 (bioaktivator rumen sapi + Mikoriza).

\section{Pemberian Mikoriza dapat} meningkatkan unsur $\mathrm{P}$ pada tanah sehingga meningkatkan pertumbuhan dan perkembangan pada tanaman, tanaman yang diinokulasi menggunakan dan Mikoriza mampu melakukan fotosintesis lebih optimal dikarnakan luas permukaan daun yang luas maka dapat melakukan fotosintesis yang baik karna daun dapat menerima radiasi matahari sebagai energi paling utama dalam proses fotosintesis (Zulaikha dan Gunawan, 2005).

Perlakuan tanah bekas M3 (bioaktivator rumen sapi + Mikoriza) ini berpengaruh nyata diduga karena adanya bakteri dan mikroorganisme yang ada pada rumen sapi. Adapun yang terkandung adalah protein sebesar $8,86 \%$, lemak $2,60 \%$, serat kasar $28,78 \%$, fosfor $0,55 \%$ dan air $10,92 \%$ (Basri, 2012). Hal ini didukung dari hasil analisis tanah bekas macam bioaktivator dan Mikoriza (rumen sapi) mengandung $\mathrm{N}=0,15$, $\mathrm{P}=2,61, \mathrm{~K}=0,19$ (BPTP, 2020).

Sesuai dengan penelitian Juliana, (2019), bahwa pemberian bioaktivator rumen sapi berbeda nyata lebih baik dari pemberian bioaktivator ragi. Kandungan rumen sapi memiliki kalsium $1,22 \%$ dan phospor $(0,29 \%)$, dimana kegunaan rumen sapi ini dimanfaatkan sebagai bioaktivator dalam proses fermentasi, yang merupakan bahan potensial mengandung beragam mikroorganisme positif untuk mendekomposisi kompos organik (Husna, 2013). Hal ini diduga menjadi penyebab rumen sapi berpengaruh nyata terhadap berat polong kering.

Pada perlakuan kombinasi pupuk $\operatorname{anorganik}$ P1 $(1 / 2$ Urea + SP36 + KCL $)$ berpengaruh nyata terhadap jumlah daun umur 28 HST, namun tidak berpengaruh nyata terhadap tinggi tanaman, jumlah cabang, panjang akar, berat basah tanaman, berat kering tanaman, berat polong basah, berat polong kering, jumlah polong, jumlah polong cipo, jumlah biji pertanaman, berat biji pertanaman, dan berat 100 biji. Hal ini diduga karena adanya ketersediaan $\mathrm{N}, \mathrm{P}, \mathrm{K}$ yang seimbang, kombinasi pupuk tersebut cenderung dapat memenuhi kebutuhan akan unsur hara bagi tumbuhan. Sesuai dengan hasil penelitian (Palobo, Edison, Melkizedek dan Marwoto, 2016) menyatakan bahwa jumlah daun meningkat pesat pada pertumbuhan vegetatif yaitu periode umur 2835 HST dimana pemberian pupuknya diberikan pada 7 HST.

Hasil uji lanjut DMRT (duncan's multiple range test) kombinasi pupuk anorganik P1 ( $1 / 2$ Urea + SP36 + KCL) berbeda nyata dengan P2 (Urea $+1 / 2$ SP36 $+\mathrm{KCL}$ ) sedangkan P3 ( Urea + SP36 + 1/2 KCL) tidak berbeda nyata dengan P1 ( $1 / 2$ Urea + SP36 + KCL) dan P2 ( Urea + 1/2 SP36 + KCL). Pupuk anorganik memiliki unsur hara $\mathrm{N}$, $\mathrm{P}$, dan $\mathrm{K}$ yang lebih tinggi dan mampu lebih cepat dalam menyediakan unsur hara dibandingkan pupuk organik.

Pemberian pupuk $\mathrm{N}$ yang dikandung dalam pupuk kimia dapat membantu pembentukan jumlah daun pada tanaman. Gardiner dan Miller (2004), menyatakan bahwa nitrogen merupakan unsur hara yang dominan dibanding unsur lainnya dalam pertumbuhan vegetatif. Namun untuk mencapai pertumbuhan optimum harus didukung oleh kecukupan P dan K. Hal ini sesuai dengan hasil penelitian Gomies, Rehatta dan Nandissa (2012), yang menyatakan bahwa frekuensi pemberian pupuk dengan dosis yang berbeda menyebabakan hasil produksi jumlah daun yang berbeda pula dan frekuensi yang tepat akan mempercepat laju pembentukan daun. Perlakuan pupuk anorganik tidak semua berpengaruh karena $\mathrm{pH}$ nya yang rendah.

Interaksi antara perlakuan tanah bekas macam-macam bioaktivator dan Mikoriza serta pemberian kombinasi pupuk anorganik 
tidak berpengaruh nyata terhadap setiap peubah yang diamati seperti tinggi tanaman, jumlah daun, jumlah cabang, panjang akar, berat basah tanaman, berat kering tanaman, berat polong basah, berat polong kering, jumlah polong isi, jumlah polong hampa (cipo), jumlah biji, berat biji pertanaman maupun berat 100 biji.

\section{BAB V}

\section{KESIMPULAN}

\subsection{Kesimpulan}

Berdasarkan hasil analisis sidik ragam data dan pembahasan tentang pengaruh tanah bekas macam-macam bioaktivator dan Mikoriza serta kombinasi pupuk anorganik terhadap pertumbuhan dan hasil tanaman kedelai (Glycine max L. Merrill), dapat disimpulkan bahwa :

Tidak terdapat interaksi antara penggunaan tanah bekas macam-macam bioaktivator dan Mikoriza dengan kombinasi pupuk anorganik pada setiap peubah yang diamati.

Penggunaan tanah bekas M3 (bioaktivator Rumen Sapi + Mikoriza) berpengaruh nyata terhadap berat polong kering. Tetapi berpengaruh tidak nyata terhadap tinggi tanaman, jumlah daun, jumlah cabang, panjang akar, berat basah tanaman, berat kering tanaman, berat polong basah, berat polong kering, jumlah polong isi, jumlah polong hampa (cipo), jumlah biji pertanaman, berat biji pertanaman dan berat 100 biji.

Pemberian pupuk anorganik yang telah dikombinasikan antara Urea, SP-36 dan KCL berpengaruh nyata terhadap jumlah daun umur 28 HST dan berpengaruh tidak nyata terhadap tinggi tanaman, jumlah cabang, panjang akar, berat basah tanaman, berat kering tanaman, berat polong basah, berat polong kering, jumlah polong isi, jumlah polong hampa (cipo), jumlah biji pertanaman, berat biji pertanaman dan berat 100 biji.

\section{DAFTAR PUSTAKA}

Adisarwanto, T. 2005. Budidaya Kedelai dengan Pemupukan yang Efektif dan Pengoptimalan Peran Bintil Akar. Penebar Swadaya. Jakarta.

--_. 2008. Budidaya Kedelai Tropika. Cetakan 10. Penebar Swadaya. Jakarta. 76 hlm.

---. 2014. Kedelai Prodiktivitas 3 Ton/ha. Penebar Swadaya. Jakarta. 92 hlm

Amanda, Rianti. 2008. Meraup Untung Dengan Palawija. Penerbit: CV. Pringgandari. Jl. Pasar Kaler, Padalarang- Kab. Bandung Barat. Bandung.

Angga, Podesta, Fitriani. 2017. Aplikasi Bioaktivator Pupuk Cair Darah Sapi Terhadap Pertumbuhan Dan Hasil Beberapa Varietas Kacang Kedelai (Glycine max L. Merril). [skripsi

Anggi, Fitriani, Harini. 2018. Pengaruh Konsentrasi Pupuk Cair Darah Sapi Dengan Bioaktivator Terhadap Pertumbuhan dan Hasil Tanaman Kedelai (Glycine max L. Merril) Di Dataran Tinggi. [skripsi]

Arda. 2008. Dalam jurnal manfaatdan proses fermentasi. Bandung

Atman. 2014. Strategi Meningkatkan Produksi Kedelai Melalui PTT. Graha Ilmi. Yogyakarta

Balitkabi. 2018. Tahun 2018 Tahun Kedelai

http://balitkabi.litbang.pertanian.go.id/liputansinar-tani-tahun-2018-tahun

kedelai/html, diakses pada tanggal 1 Maret 2019

Basri, E. Potensi Dan Pemanfaatan Rumen Sapi Sebagai Bioaktivator. Prosiding Seminar Nasional Agroinovasi Spesifik Lokasi Untuk Ketahanan Pangan Pada Era Masyarakat Ekonomi ASEAN. Balai Pengkajian Teknologi Pertanian Lampung. Lampung. 1058 
Paloi, F, A. E. Eddison, Melkizedek dan Marwoto. 2016. Pengaruh Waktu Aplikasi Ppupuk NPK Phonska Terhadap Pertumbuhan dan Hasil Kedelai. Prosiding Seminar Hasil. Penelitian Balai Pengkajian Teknologi Pertanian (BPTP) Papua. Papua.

BPS. Badan Pusat Statistik. 2016. Produksi Tanaman Pangan. Berita Resmi Statistik Provinsi Bengkulu No. 39/07/17/X, 1 Maret 2019

BPTP, 2019. Hasil Analisis Tanah. Bengkulu

---. 2020. Hasil Analisis Tanah. Bengkulu

Budiyanto, Irwan. 2013. Cara pembuatan bioaktivator.

http://irwanbudiyanto29.blogspot.com/2013/0 3/cara-pembuatan-bioaktivator. diakses pada tanggal 01 Maret 2019

Dinas Peternakan dan Perikanan Provinsi Bengkulu . 2014. Daftar Pustaka Dinas dan Perikanan Provinsi Bengkulu Pemotongan Hewan (2014). http://www.google.co.id

Fachrudin, L. 2000. Budidaya Kacangkacangan. Kanisius. Yogyakarta. 118 hal.

Fitri, Dery, Sylvi, danVivi Yarni. 2012. Pembuatan dan Analisis Pupuk Cair Dari Limbah Darah Sapi. http://jurnalsmakpa. blogspot.com /2012/05/ normal-0false-false-false-in- $x$-nonear_2010.html. 6 April 2019.

Fredi, Kurniawan. 2015. Klasifikasi dan Morfologi Kedelai. http://fredikurniawan.com/klasifikasidan-morfologi-kacang-kedelai. Diakses pada (14 Februari 2017).

Gomies, Rehatta, Nandissa. 2012. Pengaruh Pupuk Organik Terhadap Pertumbuhan Dan Produksi Tanaman Kubis Bunga. Fakultas Pertanian. Universitas Pattimura.
Gumilar Sandi, Ginting Jonis, Silitonga Sanggam. (2013). Respons Beberapa Varietas Kedelai (Glycine max L.Merril) Terhadap Pemberian Ppupuk Guano. Jurnal Online Agroekoteknologi. ISSN No. 23376597 Vol.1 No.4

Wahyono. 2010. Daur Ulang Sampah Dan Compasting. http://sriwahyono,blongspot.com. Diakses pada 10 April 2019

Hakiki, T. Rosmayati dan Husni.2013. Respon Pertumbuhan Dan Produksi Kedelai yang Diberi Fungi Mikoriza Arbuskular Pada Tanah Salin.Jurnal Online Agroteknologi. ISSN. No.2337.6597 Vol.2 No.1 : 421-427

Herdiyantoro, D. 2013. "Rancangan Acak Faktorial Acak Lengkap dan Acak Kelompok" Fakultas Pertanian Universitas Padjajaran.

Husna Nadhifa.2013.Cara membuat pupuk cair darah sapi.http://jejak penyuluhblogspot.co.id/2013/08/cara membuat-pupuk-cair-darah.html.

Diakses pada tanggal 03 Maret 2019 21.04.

Irwan, W. A. 2006. Budidaya Tanaman Kedelai (Glycine $\max$ L. Merril) Universitas Padjajaran, Jatinangor.

Nopriansyah, Fiana, Suryadi. 2016. Pengaruh Macam-macam Bioaktivator dan Konsentrasi Darah Sapi Terhadap Pertumbuhan dan Hasil Kedelai. [skripsi].

Nugroho, 2007. Deskripsi Variates Unggul Kacang-kacangan dan Umbi-umbian. Balai Penelitian Tanaman Kacangkacangan dan Umbi-umbian, Malang. $171 \mathrm{hlm}$.

Nuranto, A. 2008. Jual Blood Meal (Tepung Darah Sapi).

Padjar. 2010. Kedelai Setelah Satu Dekade. Majalah Tempo. http://majalah.tempointeraktif.com/id/ 
$\operatorname{arsip} / 2010 / 03 / 29 / \mathrm{EB} / \mathrm{mbm} .010 . i d . h$ tml. Diakses pada tanggal 5 Juli 2015.

Pitojo, S. 2003. Benih Kedelai. Yogyakarta.Kanisus

Purnomo, D. W, Purwoko, S. Yahya, Sujidan Amis Naipa. 2008. Tanggap Pertumbuhan dan Hasil Cabail Capsicum annum)Terhadap Inokulasi Fungi Mikoriza. Jurnal Agroteknologi. Hal 229-235

Purwoko, T. 2007. Fisio Mikroba. Bumi Aksara. Jakarta

Sakethi damar. 2018. Mikoriza :pengertian mikoriza, manfaat dan contoh mikoriza.

Saputri, J, Fiana Podesta dan Jon Yawahar. 2019. Pengaruh Pupuk Tepung Darah Sapi Yang Diperkaya Dengan Macam Bioaktivator Dan Dosis Mikoriza Terhadap Pertumbuhan dan Hasil Kedelai (Glycine Max L. Merril).[skripsi]

Sari, RRF, Aini Nurul dan Setyobudi Lilik. 2015. Pengaruhh Penggunaan Rhizobium Dan Penamabahan Mulsa Organik Jerami Padi Pada Tanaman Kedelai Hitam (Glycine max L. Merril). Jurnal Produksi Tanaman. Vol. 3 No. 8 hlm. 689-696

Soenandar, M. dan R., Heru, Tjachjono. 2012. Membuat Pestisida Organik. PT. Agromedia

Subiksa, IGM. 2002. Pemanfaatan Mikoriza Untuk Penanggulangan Lahan Kritis. Makalah Falsafah Sains. Program Pasca Sarjana Institut Pertanian Bogor. Bogor

Suhaeni, N. 2007.Petunjuk Praktis Menanam Kedelai, NUANSA. Bandung. Tim Balai Penelitian Tanah. 2005. Rekomendasi Pemupukan Tanaman Kedelai Pada Berbagai Tipe Penggunaan Lahan. Balai Penelitian Tanah. Bogor.
Sumarno dan A. G. Manshuri. 2007. Persyaratan Tumbuh dan Wilayah Produksi Kedelai di Indonesia. Pusat Penelitian dan Pengembangan Tanaman Pangan. Bogor. 74-105

Suprapti, M. L. 2003. Teknologi Pengolahan Pangan: Pembuatan Tempe. Cetakan I. Kanisius. Yogyakarta.

Sutardi. 2011. Pertumbuhan Dan Hasil Tiga Varietas Kedelai Hitam Dan Kuning Pada Sistem Jenuh Air. Prosiding Seminar Hasil Penelitian Tanaman Aneka Kacang Dan Umbi. Balai Pengkajian Teknologi Pertanian Yogyakarta. Yogyakarta. 239 hal.

Sutejo. 2002. Pupuk dan Pemupukan. Rineka Cipta. Jakarta.

Syahni, R. Dan Nelly, N. 2017. Analisis Statistic Untuk Penelitian Pertanian. Andalas University Press. Padang. 321

Taufiq Abdullah dan Sundari Titik, 2012. Respons Tanaman Kedelai Terhadap Lingkungan Tumbuh. Buletin Palawija No 23 hal. 22

Wahyono. 2010. Daur Ulang Sampah Dan Compasting. http://sriwahyono,blongspot.com. Diakses pada 10 April 2019

Wicaksono. M Imam, Rahayu Muji, Samanhudi. 2014. Pengaruh Pemberian Mikoriza dan Pupuk Anorganik Terhadap Pertumbuhan Bawang Putih. Jurnal Ilmu Ilmu Pertanian. Vol. XXIX No. 1 Maret 2014 hal 37

Wikipedia. $2018 . \quad$ Kedelai http://id.wikipedia.org/wiki/Kedelai.ht $\underline{\text { ml}}$, diakses pada 2 Maret 201916.30

Zulaikha, S., dan Gunawan, 2006. Serapan Fosfat dan Respon Fisiologis Tanaman Cabai Merah Cultivar Hot Beauty Terhadap Mikoriza dan Pupuk Fosfat Pada Tanah Ultisol. Volume 3, Nomor 2, Juli 2006, Halaman 83-92 
http://www.unlam.ac.id/bioscientiae/

(C) Program Studi Biologi FMIPA

Universitas Lambung Mangkurat. 